\title{
Lack of Accredited Clinical Training in Movement Disorders in Europe, Egypt, and Tunisia
}

\section{Tamas, Gertrud}

2020

Tamas , G , Fabbri , M , Falup-Pecurariu , C , Teodoro , T , Kurtis , M M , Aliyev , R , Bonello , M , Brozova , H , Coelho , M S , Contarino , M F , Corvol , J-C , Dietrichs , E , Ben Djebara , M , Elmgreen , S B , Groppa , S , Kadastik-Eerme , L , Khatiashvili , I , Kostic , V , Krismer , F , Mansour , A H , Odin , P , Gavriliuc , O , Olszewska, D A, Relja , M , Scheperjans , F , Skorvanek, M , Smilowska, K, Taba , P, Tavadyan, Z, Valante , R, Vujovic , B, Waldvogel , D , Yalcin-Cakmakli , G , Chitnis , S \& Ferreira , J J 2020 , ' Lack of Accredited Clinical Training in Movement Disorders in Europe, Egypt, and Tunisia ' , Journal of Parkinson's disease, vol. 10 , no. 4 , pp. 1833-1843 . https://doi.org/10.3233/JPD-202000

http://hdl.handle.net/10138/327399

https://doi.org/10.3233/JPD-202000

unspecified

acceptedVersion

Downloaded from Helda, University of Helsinki institutional repository.

This is an electronic reprint of the original article.

This reprint may differ from the original in pagination and typographic detail.

Please cite the original version. 
Lack of Accredited Clinical Training in Movement Disorders in Europe, Egypt and Tunisia

Gertrúd Tamás MD, $\mathrm{PhD}^{\mathrm{a}}$, Margherita Fabbri MD, $\mathrm{PhD}^{\mathrm{b}, \mathrm{c}, \mathrm{d}}$, Cristian Falup-Pecurariu MD, $\mathrm{PhD}^{\mathrm{e}}$, Tiago Teodoro, $\mathrm{MD}^{\mathrm{c}, \mathrm{f,g}}$, Mónica M. Kurtis $\mathrm{MD}^{\mathrm{h}}$, Rahim Aliyev MD, $\mathrm{PhD}^{\mathrm{i}}$, Michael Bonello MD ${ }^{\mathrm{j}}$, Hana Brozova MD, $\mathrm{PhD}^{\mathrm{k}}$, Miguel Soares Coelho MD, $\mathrm{PhD}^{\mathrm{c}, \mathrm{d}, \mathrm{l}}$, Maria Fiorella Contarino $\mathrm{MD}, \mathrm{PhD}^{\mathrm{m}, \mathrm{n}}$, Jean-Christophe Corvol $\mathrm{MD}, \mathrm{PhD}^{\mathrm{o}}$, Espen Dietrichs $\mathrm{MD}, \mathrm{PhD}^{\mathrm{p}}$, Mouna Ben Djebara $\mathrm{MD}^{\mathrm{q}}$, Søren Bruno Elmgreen $\mathrm{MD}^{\mathrm{r}}$, Sergiu Groppa MD, $\mathrm{PhD}^{\mathrm{s}}$, Liis Kadastik-Eerme MD, $\mathrm{PhD}^{\mathrm{t}, \mathrm{u}}$, Irine Khatiashvili $\mathrm{MD}, \mathrm{PhD}^{\mathrm{v}}$, Vladimir Kostić $\mathrm{MD}, \mathrm{PhD}^{\mathrm{w}}$, Florian Krismer MD, $\mathrm{PhD}^{\mathrm{x}}$, Alia Hassan Mansour $\mathrm{MD}, \mathrm{PhD}^{\mathrm{y}}$, Per Odin $\mathrm{MD}, \mathrm{PhD}^{\mathrm{z}}$, Olga Gavriliuc $\mathrm{MD}^{\mathrm{aa}}$, Diana Angelika Olszewska, $\mathrm{MD}, \mathrm{PhD}^{\mathrm{ab}}$, Maja Relja $\mathrm{MD}, \mathrm{PhD}{ }^{\mathrm{ac}}$, Filip Scheperjans MD, $\mathrm{PhD}^{\text {ad }}$, Matej Skorvanek MD, $\mathrm{PhD}^{\text {ae,af }}$, Katarzyna Smilowska MD, $\mathrm{PhD}^{\mathrm{ag}}$, Pille Taba MD, $\mathrm{PhD}^{\mathrm{t}, \mathrm{u}}$, Zaruhi Tavadyan $\mathrm{MD}^{\mathrm{ah}, \mathrm{ai}}$, Ramona Valante MD ${ }^{\mathrm{aj}}$, Balsa Vujovic MD, MSc ${ }^{\mathrm{ak}}$, Daniel Waldvogel MD ${ }^{\mathrm{al}}$, Gul Yalcin-Cakmakli MD ${ }^{\mathrm{am}}$, Shilpa Chitnis $\mathrm{MD}, \mathrm{PhD}^{\mathrm{an}}$, Joaquim J. Ferreira $\mathrm{MD}, \mathrm{PhD}^{\mathrm{c}, \mathrm{d}, \mathrm{ao}, *}$

aDepartment of Neurology, Semmelweis University, Budapest, Hungary

${ }^{\mathrm{b}}$ Department of Neuroscience "Rita Levi Montalcini", University of Turin, Italy

${ }^{\mathrm{c}}$ Instituto de Medicina Molecular, Lisbon, Portugal

${ }^{\mathrm{d}}$ Laboratory of Clinical Pharmacology and Therapeutics, Faculdade de Medicina, Universidade de Lisboa, Portugal

e Department of Neurology, Transilvania University, Braşov, Romania

${ }^{\mathrm{f}}$ Neurosciences Research Centre, Molecular and Clinical Sciences Research Institute, St

George's, University of London, London, UK

${ }^{\text {g} A s h f o r d ~ a n d ~ S t ~ P e t e r ' s ~ H o s p i t a l ~ N H S ~ T r u s t, ~ C h e r t s e y, ~ S u r r e y, ~ U K ~}$ 
${ }^{\mathrm{h}}$ Movement Disorders Unit, Neurology Department, Hospital Ruber Internacional, Madrid, Spain

iDepartment of Neurology and Clinical Neurophysiology, Azerbaijan State Advanced Training Institute for Doctors named after A.Aliyev, Baku, Republic of Azerbaijan jDepartment of Neurology, The Walton Centre NHS Foundation Trust, Liverpool, UK ${ }^{k}$ Department of Neurology and Center of Clinical Neuroscience, Charles University, First Faculty of Medicine, Prague, Czech Republic

${ }^{1}$ Neurology Service, Department of Neurosciences, Hospital Santa Maria, Lisbon, Portugal ${ }^{m}$ Department of Neurology, Leiden University Medical Center, Leiden, The Netherlands ${ }^{\mathrm{n}}$ Department of Neurology, Haga Teaching Hospital, The Hague, The Netherlands oSorbonne Université, Assistance Publique Hôpitaux de Paris, Inserm, CNRS, Hôpital PitiéSalpêtrière, Institut du Cerveau et de la Moelle, Department of Neurology, Paris, France pDepartment of Neurology, Oslo University Hospital and University of Oslo, Oslo, Norway ${ }^{\mathrm{q}}$ Department of Neurology, Razi Hospital, Faculté de Médecine de Tunis, University Tunis-El Manar, Tunisia

${ }^{\mathrm{r}}$ Department of Neurology, Aalborg University Hospital, Aalborg, Denmark ${ }^{\text {s}}$ Movement Disorders, Imaging and Neurostimulation, Department of Neurology, University Medical Center of the Johannes Gutenberg University, Mainz, Germany tDepartment of Neurology and Neurosurgery, University of Tartu, Tartu, Estonia unepartment of Neurology, Tartu University Hospital, Tartu, Estonia

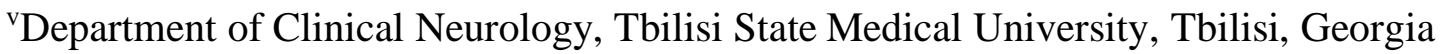

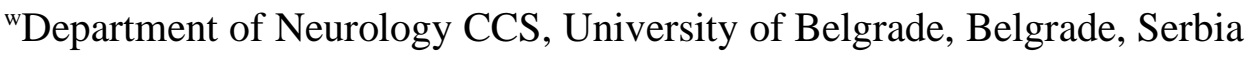
${ }^{x}$ Department of Neurology, Medical University Innsbruck, Innsbruck, Austria ${ }^{y}$ Department of Neurology, Faculty of Medicine, Ain Shams University, Cairo, Egypt ${ }^{z}$ Division of Neurology, Department of Clinical Sciences, Lund University, Lund, Sweden 
${ }^{\text {aa }}$ Department of Neurology, State University of Medicine and Pharmacy Nicolae

Testemitanu, Chisinau, Republic of Moldova

${ }^{\mathrm{ab}}$ Department of Neurology, Dublin Neurological Institute at the Mater Misericordiae

University Hospital, Dublin, Ireland

${ }^{\text {ac}}$ Croatian Academy of Medical Sciences and School of Medicine, Zagreb University, Zagreb, Croatia

${ }^{\mathrm{ad}}$ Department of Neurology, Helsinki University Hospital, and Department of Neurological Sciences (Neurology), University of Helsinki, Helsinki, Finland

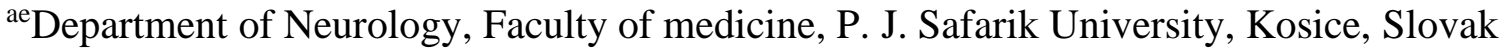
Republic

afDepartment of Neurology, University Hospital L. Pasteur, Kosice, Slovak Republic ${ }^{\mathrm{ag}}$ Silesian Center of Neurology, Katowice, Poland

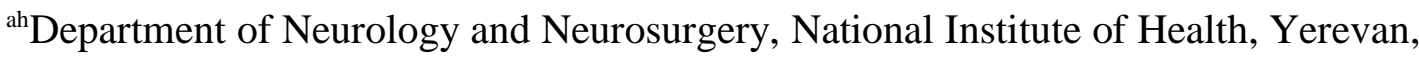
Armenia

ai"Somnus" Sleep and Movement Disorders Clinic, Yerevan, Armenia ${ }^{\text {aj} D e p a r t m e n t ~ o f ~ N e u r o l o g y, ~ P a u l s ~ S t r a d i n ̧ s ̌ ~ C l i n i c a l ~ U n i v e r s i t y ~ H o s p i t a l, ~ R i g a, ~ L a t v i a ~}$ ${ }^{\mathrm{ak}}$ Department of Neurology, Clinical Center of Montenegro, Podgorica, Montenegro

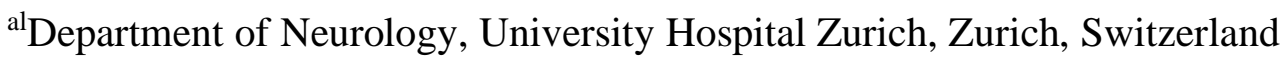
${ }^{a m}$ Department of Neurology, Hacettepe University, Ankara, Turkey

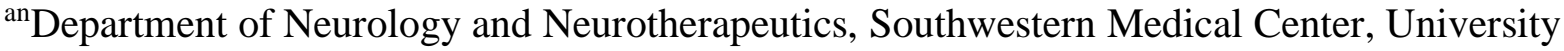
of Texas, Dallas, Texas, US

${ }^{a \circ}$ CNS - Campus Neurológico Sénior, Torres Vedras, Portugal

\section{Running title: Movement Disorders Training in Europe}


*Corresponding author:

Prof. Joaquim J Ferreira MD, PhD

Laboratorio de Farmacologia Clínica e Terapêutica

Faculdade de Medicina de Lisboa

Av. Prof. Egas Moniz

1649-028 Lisboa

Portugal

Phone + 351217802120

Fax + 351217802129

jferreira@medicina.ulisboa.pt 


\section{Abstract}

BACKGROUND: Little information is available on the official postgraduate and subspecialty training programs in movement disorders (MD) in Europe and North Africa. OBJECTIVE: To survey the accessible MD clinical training in these regions. METHODS: We designed a survey on clinical training in MD in different medical fields, at postgraduate and specialized levels. We assessed the characteristics of the participants and the facilities for MD care in their respective countries. We examined whether there are structured, or even accredited postgraduate, or subspecialty MD training programs in neurology, neurosurgery, internal medicine, geriatrics, neuroradiology, neuropediatrics, and general practice. Participants also shared their suggestions and needs.

RESULTS: The survey was completed in 31/49 countries. Structured postgraduate MD programs in neurology exist in 20 countries; structured neurology subspecialty training exists in 14 countries and is being developed in two additional countries. Certified neurology subspecialty training was reported to exist in 7 countries. Recommended reading lists, printed books, and other materials are the most popular educational tools, while courses, lectures, webinars, and case presentations are the most popular learning formats. Mandatory activities and skills to be certified were not defined in $15 / 31$ countries. Most participants expressed their need for a mandatory postgraduate MD program and for certified MD sub-specialization programs in neurology.

CONCLUSIONS: Certified postgraduate and subspecialty training exists only in a minority of European countries and was not found in the surveyed Egypt and Tunisia. MD training should be improved in many countries.

Keywords: Movement disorders, Parkinson's disease, education, curriculum, neurology 


\section{Introduction}

The topic of movement disorders (MD) is a fundamental part of neurology training in the gradual medical education and at the postgraduate level (training before neurology specialist certification) and even in the sub-specialization (becoming competent in a distinct practice area within neurology, after specialist certification). Certified MD subspecialty training programs exist in medical universities in the United States of America (USA) and Canada; however, they are not nationally standardized [1]. There is currently little information on the structure of postgraduate and subspecialty MD training in Europe and North Africa. An assessment of which countries have organized mandatory or optional programs at the different training levels, what their contents are, and how they relate to available facilities in the local MD centers is lacking. Thus, our main goal was to characterize the postgraduate and subspecialty MD training programs available throughout Europe and North Africa.

\section{Methods}

A survey was developed within the framework of the International Parkinson and Movement Disorder Society (MDS). This survey was sent to countries affiliated with the MDS-European Section [2] (Europe, North Africa, Russia, and Southwest Asia) in 2018.

We assigned one MDS member from each country to complete the survey. Each participant was asked to provide educational information on a national level. We requested that they consult the appropriate personnel and colleagues, as needed, to provide reliable data. We selected participants from the MDS Young Members Group, the MDS Leadership Development and Training Program, and other members of the MDS. The survey consisted of four different parts (Supplement 1). We assessed the characteristics of the participants in Part I and of the country in Part II, with special emphasis on how medical care is established for MD and which invasive therapies are available. The number of MD centers, as well as of 
MD specialists (working in tertiary referral MD centers) are estimations as their definition is not clarified in many countries. Part III surveyed whether there is structured or accredited postgraduate subspecialty MD training for the following medical fields: neurology, neurosurgery, internal medicine, geriatrics, neuroradiology, neuropediatrics, and general medical practice. Neurologists reported on these programs as MD is primarily a neurological topic, neurologists and neurological associations organize MD training also for other specialties. The length of training, the tools, and the highlighted topics were appraised in detail in each medical specialty. Necessary compliances for the neurology postgraduate and subspecialty trainings were further explored. When the participant reported on accredited training at each level the accrediting body was also provided. In Part IV, we asked the participants to give their opinions on how MD education could be developed further nationally, and what their needs were. Ethical approval was not required for this study because applied medical care and educational methods were analyzed. We used descriptive statistics for data presentation. We calculated the number of facilities/ 1 million inhabitants as relative numbers. We performed the Mann-Whitney rank-sum test to compare the number of facilities in countries with and without certified MD subspecialty training. The level of statistical significance was established at $\mathrm{p}<0.05$.

\section{Results}

We sent surveys to 49 countries and received data from 31 of them (Fig 1). We did not receive answers from Algeria, Morocco, Albania, Belarus, Belgium, Bosnia and Herzegovina, Bulgaria, Cyprus, Greece, Iceland, Israel, Lithuania, Luxembourg, Macedonia, Russia, Seychelles, Slovenia, and the Ukraine.

\section{Part I}


The age of participants was $42.4 \pm 10.10$ years (mean \pm SD). They qualified as a medical doctor in an average of $16.7 \pm 9.60$ years. All were neurologists and $90 \%$ were specialized. Seventyone percent had a Ph.D and all were involved in research activities. Seventy-one percent worked as movement disorder specialists; $35 \%$ also worked in general neurology; $3 \%$ had a resident assignment. Ninety-seven percent were employed in an academic/university hospital; $13 \%$ had a position in private practice, and $6 \%$ in a state hospital.

\section{Part II}

Facilities for MD patient care are summarized in Table 1. In the surveyed countries, the median relative number of MD centers was 0.49 (IQR: 0.3-0.8). The highest relative number of MD centers was reported from Austria, Portugal, and Norway. The median relative number of neurologists was 71.2 (IQR: 38-102.4). The highest relative number of physicians considered to be experts in MD was found in Austria, Italy, and Estonia. The median number of MD experts in the countries was 1.53 (IQR: 0.8-3.77). Four countries did not have an MD society or section. The median relative number of deep brain stimulation (DBS) centers was 0.28 (IQR: 0.01-0.49), while that of botulinum toxin (BTX) centers was 0.97 (IQR: 0.511.83). DBS was available in 25 of the 31 countries and was started $18 \pm 5.91$ (mean \pm SD) years ago. The highest relative numbers of DBS surgeries were reported from Norway, Finland, and The Netherlands. BTX was not available in one country.

\section{Part III}

Twenty countries (64\%) had structured MD programs (seven optional, 13 mandatory) incorporated into the neurology postgraduate training program. Most courses lasted 1-3 months. Accreditation of these courses was reported from nine countries, and Austria, Germany had certification for the postgraduate BTX training (Table 2). Responders from 14 countries (45\%) reported structured MD programs for neurology specialists, most of which last for more than one year; but these programs are only certified in 
seven countries (HR, CZ, DK, FR, NL, RS, SE; Figure 1, Table 2). MD specialist training is currently under development in Poland and Switzerland. Austria, Germany, and The Netherlands have certified BTX training for neurologists.

Regarding specialties other than neurology, the most structured MD program was reported for neurosurgeons and neuropediatricians (Table 2). Neuroradiology exists as a subspecialty in 14 countries (45\%), and neuropediatrics in 20 countries (65\%). Sweden and France have MD training available for most specialties (Sweden: neurology, neurosurgery, geriatrics and neuroradiology; France: neurology, neurosurgery, and neuropediatrics) (Table 2). In The Netherlands, ParkinsonNet actively provides Parkinson training to neurologists and allied health professionals with specific recognitions [3].

There was no difference in the relative number of MD experts, MD centers, DBS centers, DBS implantations in 2017, and BTX centers between countries that do and do not have certified MD sub-specialization (Table 3). Neurology training in most countries covered the following main topics: Parkinson's disease (PD), atypical Parkinsonism, chorea, dystonia, and tremor (Table 4). In most countries, the MD program for neurosurgeons focuses on DBS indications (PD, dystonia, and tremor) in addition to the basic neuroscience of MDs and functional neurosurgery (including DBS). Various MD topics are covered by other specialties.

In order to fulfill the postgraduate MD program, five countries require a minimum number of MD patients examined in the hospital and outpatient clinic, and treated by BTX and advanced therapies. It is a requirement for subspecialty training in four countries (Table 5). No country requires a specific number of first and follow-up visits. Training in application of clinical scales and neuropathology are parts of the postgraduate neurology curriculum in most reporting countries. Courses on using clinical scales, jejunal levodopa pump and BTX therapy are offered to neurology specialists in most countries. Teaching is an expectation of 
MD subspecialty training in five countries, research in eight countries, and performing presentations in MD conferences in nine countries (Table 5).

Regarding learning materials, recommended readings and printed books/materials are the most popular, both for postgraduate and subspecialty MD training (Fig 2). This material is often free for all or free for program participants, and members of the national MD section, or access can be bought. The most popular educational activities are courses/lectures/webinars or case presentations with experienced tutors.

\section{Part IV}

Most responders are of the opinion that there is a need for a mandatory postgraduate MD program with a longer duration (more than one month) and an extended curriculum for neurologists. They would like to have a certified MD specialty in their countries. Optional MD training was also suggested for specialties other than neurology, supporting the concept of interdisciplinary care for MDs. Responders are of the opinion that the requirements for an MD center should be defined. Rotation between MD centers and more fellowship opportunities to MD centers abroad could be beneficial; one responder considered that it should be mandatory for a MD Specialist Certification. In many countries there is a need for regular comprehensive MD courses with invited speakers. There was a suggestion that access to video education material with interpretation would be helpful for local educational activities.

\section{Discussion}

The results of our survey highlight that certified postgraduate and subspecialty MD training exists only in a minority of the surveyed countries.

Indeed, we found that the postgraduate education for MDs is not well structured in most countries. MD sub-specialization is available in 14/31 (45\%) countries for neurologists; it is 
accredited in only $7 / 31(22 \%)$ countries and is under development in two additional countries.

In the 1990s, following the rapid scientific and therapeutic advancements that were taking place in the field, traditional training in general neurology required sub-specialization $[4,5]$. It is still a matter of debate as to whether sub-specializations have a positive or negative impact on patient care or on the professional motivation of physicians. All in all, it is still a principle that sub-specializations should be built on the knowledge of general neurology in order for the appropriate clinical diagnosis and proper care to be provided [6]. Sub-specialization is beneficial in many aspects. The health care environment in many countries favors the accountability of physicians with a high patient volume, and therefore, proficiency in skills [5]. It has been demonstrated that the diagnosis of Parkinson's disease (PD) is more accurate in a movement disorder clinic [7] than in a general neurological practice [8]. Moreover, specialists are better able to manage non-motor and motor complications in PD than general neurologists [9]. In 1997, the European Parkinson's Disease Association and the World Health Organization declared that PD patients want the right to be referred to a doctor with a special interest in PD [10].

The optimal position of MD experts should be found in patient care networks; their role should at least be in initial diagnosis and infrequent follow-ups [11], depending on the applied therapy and general needs of the country.

In the USA, many universities have announced MD fellowship training [1]. These fellowship programs are often flexible; the participants can visit multiple training centers with the assistance of the San Francisco residency and fellowship match services supervised by an expert committee [12]. This program is not consistent with others in the region as it is not endorsed by the two main certifying bodies, the Accreditation Council for Graduate Medical Education (ACGME) or the United Council for Neurologic Subspecialties (UCNS) [13]. The 
program is instead certified by the Institutional Graduate Medical Office (GME) and the State Medical Board. The UCNS was initiated by the American Academy of Neurology in 2001 for the USA and Canada to provide accreditation and certification of neurological subspecialty fellowship programs [4]. However, it has identified nine subspecialties until now, not including the recognition of MD for which no application has been made.

In Europe, Egypt and Tunisia, we have found that MD subspecialty training does not exist or is not accredited in most countries, even though MD is the most popular field among European neurology residents and is often a future sub-specialization for young neurologists [14].

The existing certified programs have not yet had an impact on the number of MD experts and facilities of care in the different countries, maybe because of their short history. Twenty-two countries have had DBS for more than 10 years and there is no certified subspecialty MD training in 16 of them (Table 1). Training for invasive therapies such as BTX, DBS, and jejunal levodopa pump are principally set up by the respective companies without any agreement between them and countries regarding curriculum and eligibility requirements. The MDS also offers optional and international courses in these topics. We explored that conventional educational tools and activities are widely used instead of internet-based educational materials, which would better support the contemporary educational formats including the flipped classroom approach and interactive, social learning [15].

The limitations of our study are that we did not get an answer from $36,7 \%$ of the countries, and we asked one clinician from each country. However, the participants from 30/31 countries were employed in a university, and they were all MDS members. They consulted with relevant colleagues in universities, societies, agencies, offices, companies, and took full responsibility for the declared numbers and answers. 
According to our results, the term movement disorders specialist and movement disorders center is unofficially defined in most of the countries. Many countries wish to improve their teaching methods for MD, which would be beneficial in the quality assurance of clinical care. The structure of education programs and a curriculum (the optimal duration of the training, educational formats, and the certifying body) could be implemented in each country according to local authority requirements. MDS could support these initiatives with a core curriculum. MD rotations could offer the opportunity to visit experienced MD centers and study the diagnostics and management of patients with a complex MD, as well as advanced therapies. Early identification of trainees interested in MD would be beneficial. Roles for MD specialists and licensing requirements of an MD center should be determined. Setting up a structured network with tertiary, highly specialized hospitals would promote the care of difficult MD cases. The opinions about the need for certification are controversial; nevertheless, it is an educational tool, which guarantees a standard in medical training and quality in medical care. Local laws should determine the way of certification in each country, in which an MDS-ES exam could optionally count.

\section{Acknowledgments:}

The study had no funding.

\section{Conflict of interest:}

MB reports personal fees from Britannia Pharmaceuticals, personal fees from AbbVie Inc, outside the submitted work.

FC reports travel support from Boston Scientific, grants from Medtronic and AbbVie, fee of consultancies from CHDR, personal fees from Novartis Pharma BV, non-financial support from Global Kinetics Corporation, outside the submitted work. 
JCC reports grants from Sanofi, personal fees from Idorsia, Ever Pharma, Denali, Biogen, Air Liquide, Brainerver and Theranexus, outside the submitted work.

JJF reports grants from GlaxoSmithKline, Grunenthal, Fundação MSD (Portugal), TEVA, MSD, Allergan, Novartis, Medtronic, GlaxoSmithKline, Novartis, TEVA, Lundbeck, Solvay,

BIAL, Merck-Serono, Merz, Ipsen, Biogen, Acadia, Allergan, Abbvie and Sunovion

Pharmaceuticals; personal fees from Faculdade de Medicina de Lisboa, CNS - Campus

Neurológico Sénior, BIAL and Novartis, outside the submitted work.

FK reports grant from MSA Coalition, outside the submitted work.

FS reports personal fees and non-financial support from Abbvie, UCB, Herantis Pharma, Zambon and Livanova; non-financial support from NordicInfu Care, Medtronic, Global Kinetics Corporation and Abbott; other from NeuroInnovation Oy; personal fees from Orion, outside the submitted work.

GT reports grant from Medtronic, non-financial support from Abbott and Krka, personal fees from UCB, outside the submitted work.

\section{Supplementary material}

\section{Supplement 1}

The survey of the education of movement disorder specialists

\section{References}

1. Portera-Cailliau C, Victor D, Frucht S, Fahn S (2006) Movement disorders fellowship training program at Columbia University Medical Center in 2001-2002. Mov Disord 21, 479-485.

2. https://www.movementdisorders.org/MDS-ES, Accessed March 6, 2020.

3. https://www.parkinsonnet.nl, Accessed March 6, 2020. 
4. Vespa PM, Sergay SM, Kohring JH (2011) Subspecialization in neurology: the role of the United Council for Neurologic Subspecialties. Neurology 77, 1702-1705.

5. Cassel CK, Reuben DB (2011) Specialization, subspecialization, and subsubspecialization in internal medicine. $N$ Engl J Med 364, 1169-1173.

6. Szirmai I (2010) [Neurology! Adieau? (Part 1)]. Ideggyogy Sz 63, 148-155.

7. Hughes AJ, Daniel SE, Ben-Shlomo Y, Lees AJ (2002) The accuracy of diagnosis of parkinsonian syndromes in a specialist movement disorder service. Brain 125, 861870.

8. Schrag A, Ben-Shlomo Y, Quinn N (2002) How valid is the clinical diagnosis of Parkinson's disease in the community? J Neurol Neurosurg Psychiatry 73, 529-534.

9. Cheng EM, Swarztrauber K, Siderowf AD, Eisa MS, Lee M, Vassar S, Jacob E, Vickrey BG (2007) Association of specialist involvement and quality of care for Parkinson's disease. Mov Disord 22, 515-522.

10. Baker MG, Graham L (2004) The journey: Parkinson's disease. Bmj 329, 611-614.

11. Farbman ES (2011) The case for subspecialization in neurology: movement disorders. Front Neurol 2, 22.

12. https://www.sfmatch.org, Accessed March 6, 2020.

13. www.ucns.org, Accessed March 6, 2020.

14. Zis P, Macerollo A, Sauerbier A, Papp V, Klingelhoefer L, Cock HR (2018) Subspecialty preferences among neurologists of the future. Eur J Neurol 25, 597-601.

15. Stephens MB, McKenna M, Carrington K (2011) Adult learning models for largegroup continuing medical education activities. Fam Med 43, 334-337. 
Table 1. Country characteristics, facilities for the care of movement disorders

\begin{tabular}{|c|c|c|c|c|c|c|c|}
\hline Country & $\begin{array}{l}\text { Total } \\
\text { popu- } \\
\text { lation } \\
\text { in } 2017 \\
\left(10^{6}\right)^{\star}\end{array}$ & $\begin{array}{l}\text { No. of MD } \\
\text { centers/ } \\
\text { DBS centers/ } \\
\text { BTX units } \\
\text { (estimation) }\end{array}$ & 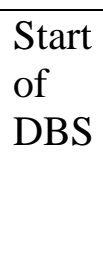 & $\begin{array}{l}\text { No. of } \\
\text { DBS } \\
\text { implan- } \\
\text { tations } \\
\text { in } 2017\end{array}$ & $\begin{array}{l}\text { No. of } \\
\text { MD } \\
\text { organi- } \\
\text { zations, } \\
\text { sections }\end{array}$ & $\begin{array}{l}\text { No. of } \\
\text { Faculties } \\
\text { of } \\
\text { Medicine }\end{array}$ & $\begin{array}{l}\text { No. of MD } \\
\text { experts/ neuro- } \\
\text { logists (per } 1 \\
\text { million people; } \\
\text { estimation) }\end{array}$ \\
\hline Armenia (AM) & 2.930 & $1 / 0 / 2$ & - & 0 & 1 & 4 & $0.68 / 102.39$ \\
\hline Austria (AT) & 8.735 & $32 / 5 / 15$ & 1999 & 40 & 1 & 5 & $13.74 / 129.13$ \\
\hline Azerbaijan (AZ) & 9.827 & $3 / 0 / 10$ & - & 0 & 1 & 2 & $1.02 / 71.23$ \\
\hline Croatia (HR) & 4.189 & $3 / 1 / 4$ & 1995 & 12 & 1 & 4 & $4.77 / 83.55$ \\
\hline Czech Republic (CZ) & 10.618 & $3 / 3 / 29$ & 1998 & 50 & 1 & 8 & $2.35 / 84.76$ \\
\hline Denmark (DK) & 5.778 & $14 / 2 / 9$ & 1997 & 50 & 1 & 4 & $5.19 / 46.73$ \\
\hline Egypt (EG) & 97.553 & $8 / 1 / 7$ & 2001 & 6 & 2 & 25 & $1.54 / 20.5$ \\
\hline Estonia (EE) & 1.309 & $2 / 1 / 5$ & 2006 & 4 & 1 & 1 & $7.64 / 109.24$ \\
\hline Finland $(\mathrm{FI})$ & 5.523 & $5 / 5 / 25$ & 1995 & 110 & 1 & 5 & $3.62 / 78.4$ \\
\hline France (FR) & 64.979 & $25 / 20 / 50$ & 1986 & 400 & 4 & 37 & $3.08 / 38.01$ \\
\hline Georgia (GE) & 3.912 & $2 / 1 / 2$ & $\begin{array}{l}\approx \\
2020\end{array}$ & 0 & 1 & 5 & $1.28 / 187.88$ \\
\hline Germany (DE) & 82.114 & $24 / 40 / 250$ & 2000 & 700 & 25 & 24 & NA/121.78 \\
\hline Hungary (HU) & 9.721 & $4 / 5 / 7$ & 1998 & 120 & 2 & 4 & $2.57 / 88.67$ \\
\hline Ireland (IE) & 4.761 & $7 / 1 / 5$ & 2009 & 0 & 0 & 6 & $1.05 / 7,56$ \\
\hline Italy (IT) & 59.359 & $30 / 29 / 60$ & 1996 & 280 & 1 & 40 & $8.81 / 109.05$ \\
\hline Latvia (LV) & 1.949 & $0 / 0 / 1$ & 2005 & 0 & 1 & 2 & $1.03 / 145.2$ \\
\hline Montenegro (ME) & 0.628 & $0 / 0 / 1$ & - & 0 & 0 & 1 & NA/44.59 \\
\hline $\begin{array}{l}\text { The Netherlands } \\
\text { (NL) }\end{array}$ & 17.035 & $10 / 6 / 50$ & 1993 & 250 & 1 & 8 & $1.76 / 46.96$ \\
\hline Norway (NO) & 5.305 & $\begin{array}{l}15 \text { (1 formal }) \\
/ 2 / 20\end{array}$ & 1995 & 110 & 1 & 4 & $3.77 / 87.84$ \\
\hline Poland (PL) & 38.170 & $\begin{array}{l}15 \text { adult+3 } \\
\text { children/18/7 } \\
0\end{array}$ & 1999 & 334 & 2 & 21 & $\mathrm{NA} / 112.7$ \\
\hline Portugal (PT) & 10.329 & $32 / 6 />10$ & 2002 & 30 & 1 & 6 & $5.03 / 34.95$ \\
\hline $\begin{array}{l}\text { Republic of } \\
\text { Moldova (MD) }\end{array}$ & 4.051 & $1 / 0 / 0$ & - & 0 & 0 & 1 & $1.23 / 74.06$ \\
\hline Romania (RO) & 19.679 & $8 / 2 / 6$ & 2004 & 6 & 0 & 12 & NA/40.65 \\
\hline $\begin{array}{l}\text { Republic of Serbia } \\
\text { (RS) }\end{array}$ & 8.790 & $4 / 0 / 3$ & - & 0 & 1 & 6 & $0.8 / 51.19$ \\
\hline $\begin{array}{l}\text { Slovak Republic } \\
\text { (SK) }\end{array}$ & 5.447 & $4 / 3 / 17$ & 2002 & 30 & 1 & 3 & $1.84 / 91.79$ \\
\hline Spain (ES) & 46.354 & 8/8/ND & 1998 & ND & 17 & 47 & NA/34.67 \\
\hline Sweden (SE) & 9.910 & $7 / 6 / 6$ & 1993 & 60 & 2 & 7 & $3.53 / 32.29$ \\
\hline Switzerland $(\mathrm{CH})$ & 8.476 & $7 / 4 / 7$ & 1998 & 100 & 1 & 6 & $4.72 / 70.79$ \\
\hline Tunisia (TN) & 11.532 & $2 / 0 / 3$ & 2006 & 0 & 1 & 4 & $0.35 / 18.04$ \\
\hline Turkey (TR) & 80.745 & $40 / 15 / 60$ & 1999 & 572 & 2 & 84 & $0.93 / 61.92$ \\
\hline $\begin{array}{l}\text { United Kingdom } \\
\text { (UK) }\end{array}$ & 66.181 & $50 / 16 / 89$ & 1997 & 300 & 2 & 36 & $1.51 / 13.67$ \\
\hline
\end{tabular}

http://worldpopulationreview.com/countries/; MD: movement disorder; DBS: deep brain stimulation; BTX: botulinum toxin; ND: no data; N: no; Y: yes 
Table 2. Structured movement disorder programs at postgraduate and specialized levels in different specialties as reported by the different countries. Official accreditation is listed if it exists

\begin{tabular}{|c|c|c|c|}
\hline $\begin{array}{l}\text { Specialty/ } \\
\text { level of training }\end{array}$ & $\begin{array}{l}\text { Structured MD program } \\
\text { exists }\end{array}$ & Duration (Month) & Accrediting body \\
\hline $\begin{array}{l}\text { Neurology/ } \\
\text { Postgraduate }\end{array}$ & $\begin{array}{l}\text { Optional: AM, AT , DE , } \\
\text { GE, IT, NL, SE, CH, PT } \\
\text { Mandatory: AM, AZ, } \\
\text { HR, EG, FR, GE, HU, } \\
\text { IE, ME, MD, ES, TR, } \\
\text { UK }\end{array}$ & $\begin{array}{l}\leq 1: \mathrm{GE}, \mathrm{HU}, \mathrm{SE} \\
\text { 1-3: AM, AZ, } \\
\text { HR, EG, IT, ME, } \\
\text { MD, ES } \\
\text { 3-6: FR, PT, TR } \\
\text { 6-12: IE, NL }\end{array}$ & $\begin{array}{l}\text { AM: Ministry of } \\
\text { Education and } \\
\text { Science, AT : c,d; } \\
\text { HR: a, FR: e, GE: } \\
\text { a, DE: d, IE: a; } \\
\text { ME: b,e; MD: a, } \\
\text { NL: e; SE: b }\end{array}$ \\
\hline $\begin{array}{l}\text { Neurology/ } \\
\text { Subspecialty }\end{array}$ & $\begin{array}{l}\text { AT, AZ, HR, CZ, DK, } \\
\text { EG, ES, FR, DE , NL, } \\
\text { PT, RS, SE, SK, TR, UK }\end{array}$ & $\begin{array}{l}\leq 1: \text { AZ, EG, SE } \\
\text { 3-6: HR } \\
\text { 6-12: RS, FR } \\
>12: \text { CZ, DK, ES, } \\
\text { NL, SK, TR, UK }\end{array}$ & $\begin{array}{l}\text { HR: a, CZ: d, DK: } \\
\text { d, FR: e, DE: d, } \\
\text { NL: c,d; RS: b,c,e; } \\
\text { SE: Scandinavian } \\
\text { MD Society }\end{array}$ \\
\hline $\begin{array}{l}\text { Neurosurgery/ } \\
\text { Postgraduate }\end{array}$ & $\begin{array}{l}\text { Optional: AZ, EG, ME, } \\
\text { ES, SE, CH, TR, UK } \\
\text { Mandatory: HR, HU }\end{array}$ & $\begin{array}{l}\leq 1: \mathrm{AZ}, \mathrm{EG}, \mathrm{HU} \\
\mathrm{SE}\end{array}$ & ME: b,e; SE: b \\
\hline $\begin{array}{l}\text { Neurosurgery/ } \\
\text { Subspecialty }\end{array}$ & $\begin{array}{l}\text { AZ, EG, ES, FR, HU, } \\
\text { SE, TR, UK }\end{array}$ & $\begin{array}{l}\leq 1: \mathrm{AZ}, \mathrm{EG}, \mathrm{SE} \\
\text { 1-3: HU, TR } \\
\text { 6-12: FR } \\
\text { >12: ES, UK }\end{array}$ & $\begin{array}{l}\text { FR: e, SE: } \\
\text { Scandinavian MD } \\
\text { Society }\end{array}$ \\
\hline $\begin{array}{l}\text { Internal Medicine/ } \\
\text { Postgraduate }\end{array}$ & Mandatory: $\mathrm{CH}, \mathrm{HR}, \mathrm{IE}$ & 1-3: IE & IE: a \\
\hline $\begin{array}{l}\text { Internal Medicine/ } \\
\text { Subspecialty }\end{array}$ & - & - & - \\
\hline $\begin{array}{l}\text { General practitioner/ } \\
\text { Postgraduate }\end{array}$ & Mandatory: HR & & \\
\hline $\begin{array}{l}\text { General practitioner/ } \\
\text { Subspecialty }\end{array}$ & - & - & - \\
\hline $\begin{array}{l}\text { Geriatrician/ } \\
\text { Postgraduate }\end{array}$ & $\begin{array}{l}\text { Mandatory: EG, IE, UK } \\
\text { Optional: IT, ES, SE, TR }\end{array}$ & $\begin{array}{l}\leq 1: \mathrm{SE} \\
\text { 1-3: IT } \\
\text { 3-6: IE }\end{array}$ & IE: $a, S E: b$ \\
\hline $\begin{array}{l}\text { Geriatrician/ } \\
\text { Subspecialty }\end{array}$ & SE, TR & $\begin{array}{l}\leq 1: \mathrm{SE} \\
1-3: \mathrm{TR}\end{array}$ & $\begin{array}{l}\text { SE: Scandinavian } \\
\text { MD Society }\end{array}$ \\
\hline $\begin{array}{l}\text { Neuroradiologist/ } \\
\text { Postgraduate }\end{array}$ & Optional: SE & $\leq 1: \mathrm{SE}$ & SE: $b$ \\
\hline $\begin{array}{l}\text { Neuroradiologist/ } \\
\text { Subspecialty }\end{array}$ & EG, SE & $\leq 1: \mathrm{SE}$ & $\begin{array}{l}\text { SE: Scandinavian } \\
\text { MD Society }\end{array}$ \\
\hline $\begin{array}{l}\text { Neuropediatrician/ } \\
\text { Postgraduate }\end{array}$ & $\begin{array}{l}\text { Mandatory: AM, EG, } \\
\text { ME, RS, UK } \\
\text { Optional: PT, TR, IT }\end{array}$ & $\begin{array}{l}\leq 1: \text { EG } \\
1-3: \text { PT, IT }\end{array}$ & ME: b, e \\
\hline $\begin{array}{l}\text { Neuropediatrician/ } \\
\text { Subspecialty }\end{array}$ & EG, ES, FR, IE, TR, UK & $\begin{array}{l}\leq 1: \mathrm{EG}, \mathrm{UK} \\
1-3: \mathrm{IE}\end{array}$ & FR: e, IE: a \\
\hline
\end{tabular}




\section{3-6: TR, \\ 6-12: FR \\ $>12$ : ES}

only for Botulinum toxin; a: National Board of Medical Specialties/General Medical Council independent from the government, b: General Medical Board/Council belonging to the Ministry of Health; c: National Neurological Society; d: National Movement Disorders Society; e: University Hospital 
Table 3. Relationship of the resources in patient care and the existence of certified movement disorder training

\begin{tabular}{|lll|}
\hline Relative number & $\begin{array}{l}\text { Median (inter-quartile range) } \\
\text { Certified/non-certified training }\end{array}$ & $\begin{array}{l}\text { Difference between countries } \\
\text { with certified and non-certified } \\
\text { MD training }\end{array}$ \\
\hline MD experts & $\begin{array}{l}3.08(1.76-4.77) / 1.25(0.51- \\
3.69)\end{array}$ & $\mathrm{U}=55 ; \mathrm{Z}=1.37 ; \mathrm{p}=0.17$ \\
\hline MD centers & $\begin{array}{l}0.58(0.38-0.72) / 0.48(0.27- \\
0.86)\end{array}$ & $\mathrm{U}=76 ; \mathrm{Z}=0.35 ; \mathrm{p}=0.73$ \\
\hline DBS centers & $0.31(0.24-0.35) / 0.24(0-0.5)$ & $\mathrm{U}=80 ; \mathrm{Z}=0.19 ; \mathrm{p}=0.85$ \\
\hline BTX centers & $\begin{array}{l}0.95(0.6-2.73) / 0.99(0.51- \\
1.77)\end{array}$ & $\mathrm{U}=81 ; \mathrm{Z}=0.14 ; \mathrm{p}=0.89$ \\
\hline DBS implants in 2017 & $6.05(2.86-8.65) / 3.05(0-8.52)$ & $\mathrm{U}=62 ; \mathrm{Z}=0.91 ; \mathrm{p}=0.36$ \\
\hline
\end{tabular}


Table 4. The highlighted topics of movement disorder training in the seven specialties at postgraduate and specialized educational levels

\begin{tabular}{|c|c|c|c|c|c|c|c|}
\hline \multirow[t]{2}{*}{ Topic } & \multicolumn{7}{|c|}{ Number of countries } \\
\hline & $\begin{array}{c}\mathrm{N} \\
(\mathrm{PG} / \mathrm{S})\end{array}$ & NS & I & GP & $\mathrm{G}$ & NR & NP \\
\hline Parkinson's disease & $14 / 11$ & $5 / 7$ & $1 / 0$ & & $4 / 3$ & & $1 / 3$ \\
\hline Atypical Parkinsonism & $14 / 10$ & $1 / 2$ & $1 / 0$ & & $3 / 2$ & & $0 / 4$ \\
\hline Chorea & $13 / 10$ & $2 / 4$ & $1 / 0$ & & $2 / 2$ & & $1 / 4$ \\
\hline Dystonia & $12 / 10$ & $4 / 6$ & $1 / 0$ & & $2 / 2$ & & $1 / 4$ \\
\hline Ataxia & $11 / 9$ & $1 / 2$ & $1 / 0$ & & $2 / 2$ & & $1 / 4$ \\
\hline Tremor & $10 / 10$ & $2 / 5$ & $1 / 0$ & & $2 / 2$ & & $1 / 4$ \\
\hline Tics and Tourette syndrome & $10 / 9$ & $1 / 3$ & $1 / 0$ & & $2 / 2$ & & $0 / 4$ \\
\hline Huntington's disease & $10 / 9$ & $1 / 2$ & $1 / 0$ & & $2 / 1$ & & $0 / 3$ \\
\hline Basic neuroscience of movement disorders & $8 / 9$ & $2 / 6$ & $1 / 0$ & & $1 / 1$ & & $1 / 4$ \\
\hline Myoclonus & $10 / 7$ & $1 / 2$ & $1 / 0$ & & $2 / 1$ & & $1 / 4$ \\
\hline Psychogenic movement disorders & $7 / 9$ & $0 / 2$ & $1 / 0$ & & $1 / 1$ & & $1 / 4$ \\
\hline Gait disorders & $9 / 7$ & $2 / 4$ & $1 / 0$ & & $2 / 2$ & & $1 / 3$ \\
\hline Cognitive impairment in PD & $8 / 8$ & $1 / 2$ & & & $2 / 2$ & & $0 / 1$ \\
\hline $\begin{array}{l}\text { Botulinum toxin treatment of movement } \\
\text { disorders }\end{array}$ & $6 / 9$ & $1 / 2$ & $1 / 0$ & & $2 / 1$ & & $0 / 1$ \\
\hline Genetics of movement disorders & $7 / 8$ & $1 / 2$ & & & $1 / 1$ & & $1 / 4$ \\
\hline Autonomic dysfunction & $8 / 7$ & $1 / 2$ & & & $1 / 2$ & & $1 / 1$ \\
\hline Movement disorder emergencies & $7 / 7$ & $0 / 2$ & $1 / 0$ & & $1 / 1$ & & $1 / 2$ \\
\hline Sleep disorders & $8 / 6$ & $1 / 2$ & $1 / 0$ & & $2 / 1$ & & $1 / 2$ \\
\hline Wilson's disease & $8 / 7$ & $0 / 1$ & & & $0 / 1$ & & $1 / 3$ \\
\hline Psychiatric disturbances in movement disorders & $7 / 8$ & $1 / 2$ & & & $1 / 1$ & & $0 / 1$ \\
\hline Restless leg syndrome & $8 / 7$ & $1 / 1$ & & & $1 / 1$ & & $1 / 0$ \\
\hline Neuroimaging & $8 / 6$ & $1 / 3$ & $1 / 0$ & & $2 / 0$ & $1 / 0$ & $1 / 3$ \\
\hline Paroxysmal movement disorders PG & $7 / 7$ & $0 / 1$ & $1 / 0$ & & $1 / 0$ & & $1 / 3$ \\
\hline Invasive therapies in PD & $5 / 7$ & $2 / 4$ & & & $2 / 1$ & & $0 / 1$ \\
\hline Neurobehavioral complications in PD & $6 / 6$ & $1 / 2$ & $0 / 0$ & & $2 / 2$ & & $0 / 1$ \\
\hline Functional neurosurgery (including DBS) & $3 / 8$ & $3 / 6$ & & & $0 / 1$ & & $0 / 2$ \\
\hline Spasticity & $6 / 5$ & $1 / 4$ & $1 / 0$ & & $1 / 1$ & & $1 / 3$ \\
\hline Non-pharmacological therapies in PD & $5 / 6$ & $2 / 3$ & & & $2 / 1$ & & $0 / 1$ \\
\hline Neuropharmacology & $5 / 5$ & $0 / 2$ & $1 / 0$ & & $2 / 1$ & & $1 / 2$ \\
\hline Clinical neurophysiology & $4 / 5$ & $1 / 2$ & $1 / 0$ & & $1 / 0$ & & $1 / 1$ \\
\hline $\begin{array}{l}\text { Eye movement abnormalities in movement } \\
\text { disorders }\end{array}$ & $5 / 4$ & $0 / 1$ & $1 / 0$ & & $1 / 0$ & & $0 / 3$ \\
\hline Pediatric movement disorders & $4 / 4$ & $0 / 1$ & & & & & $1 / 3$ \\
\hline $\begin{array}{l}\text { Evidence-based medicine in movement } \\
\text { disorders }\end{array}$ & $4 / 4$ & $1 / 2$ & $1 / 0$ & & $2 / 0$ & & $1 / 2$ \\
\hline Movement disorders and Internal Medicine & $4 / 4$ & & $2 / 0$ & & $1 / 1$ & & $0 / 1$ \\
\hline Rehabilitation in movement disorders PG & $1 / 6$ & & $1 / 0$ & & $1 / 0$ & & $1 / 1$ \\
\hline Neuropathology & $2 / 3$ & $0 / 1$ & $1 / 0$ & & $1 / 1$ & & $1 / 0$ \\
\hline E-Health and movement disorders & $0 / 1$ & & & & & & \\
\hline
\end{tabular}

PG: postgraduate education; S: sub-specialization; N: Neurology; NS: Neurosurgery; I: Internal Medicine; GP: General practitioner; G: Geriatrician; NR: Neuroradiologist; NP: Neuropediatrician 
Table 5. The required compliances in the neurology postgraduate and subspecialty training

\begin{tabular}{|c|c|c|}
\hline $\begin{array}{l}\text { Required compliances in } \\
\text { Neurology }\end{array}$ & Postgraduate & MD Sub-specialization \\
\hline $\begin{array}{l}\text { Patient number in an } \\
\text { outpatient clinic }\end{array}$ & $100^{\mathrm{HR}}, 50(\mathrm{in}+\mathrm{out})^{\mathrm{HU}}$ & $\begin{array}{l}150^{\mathrm{HR}}, 20^{\mathrm{FR}}, \\
100(\text { in+out+children })^{\mathrm{NL}}\end{array}$ \\
\hline $\begin{array}{l}\text { Patient number in the } \\
\text { inpatient care }\end{array}$ & $50^{\mathrm{AZ}}, 30^{\mathrm{HR}}$ & $60^{\mathrm{HR}}$ \\
\hline No of BTX cases & $10^{\mathrm{HR}}, 75^{\mathrm{DE}}$ & $30^{\mathrm{HR}}, 20^{\mathrm{FR}}, 75^{\mathrm{DE}}$ \\
\hline Patient selection for DBS & & \\
\hline $\begin{array}{l}\text { Patient selection for other } \\
\text { advanced therapies in PD }\end{array}$ & $10^{\mathrm{HR}}$ & $20^{\mathrm{HR}}$ \\
\hline Basic DBS course & & $\mathrm{CZ}, \mathrm{DK}, \mathrm{FR}, \mathrm{NL}, \mathrm{SE}$ \\
\hline $\begin{array}{l}\text { Intraoperative testing for } \\
\text { DBS }\end{array}$ & & NL \\
\hline $\begin{array}{l}\text { Basic course on jejunal } \\
\text { levodopa pump therapy }\end{array}$ & $\mathrm{HR}, \mathrm{SE}$ & HR, CZ, DK, NL, RS, SE \\
\hline $\begin{array}{l}\text { Basic course on apomorfin } \\
\text { pump therapy }\end{array}$ & $\mathrm{SE}$ & HR, DK, NL, RS, SE \\
\hline $\begin{array}{l}\text { Basic course on BTX } \\
\text { injection therapy }\end{array}$ & IE & $\begin{array}{l}\text { HR, CZ, DK, FR, NL, RS, } \\
\text { SE }\end{array}$ \\
\hline $\begin{array}{l}\text { Application of clinical } \\
\text { scales }\end{array}$ & $\mathrm{AZ}, \mathrm{HR}, \mathrm{IE}, \mathrm{MD}, \mathrm{SE}$ & AZ, HR, CZ, NL, RS, SE \\
\hline $\begin{array}{l}\text { Neurophysiological } \\
\text { assessment of movement } \\
\text { disorders }\end{array}$ & $\mathrm{AZ}, \mathrm{IE}, \mathrm{MD}$ & $\mathrm{AZ}, \mathrm{HR}, \mathrm{CZ}, \mathrm{NL}, \mathrm{RS}$ \\
\hline Neuropathology & AZ, HU, IE, MD & AZ, HR, DK, NL \\
\hline $\begin{array}{l}\text { Assistance in clinical } \\
\text { studies }\end{array}$ & HR & HR, NL, RS, TR \\
\hline $\begin{array}{l}\text { Required patient number } \\
\text { for first examination }\end{array}$ & - & \\
\hline $\begin{array}{l}\text { Required patient number } \\
\text { for follow-up visit? }\end{array}$ & - & \\
\hline Teaching & - & AZ, HR, FR, RS, TR, UK \\
\hline Research & - & $\begin{array}{l}\text { EG, IT, NL, MD, RS, SE, } \\
\text { TR, UK }\end{array}$ \\
\hline $\begin{array}{l}\text { Presentation in a } \\
\text { local/national/international } \\
\text { Movement Disorders } \\
\text { Conference }\end{array}$ & - & $\begin{array}{l}\text { AZ, HR, CZ, IT, NL, MD, } \\
\text { RS, TR, UK }\end{array}$ \\
\hline
\end{tabular}

BTX: botulinum toxin; DBS: deep brain stimulation; PD: Parkinson's disease 


\section{Figure legends}

\section{Figure 1}

Map of the participating countries. Mid and dark grey colors indicate the participating countries. Countries in dark grey have certified movement disorder subspecialty training for neurologists. In each country, the estimated number of MD centers/MD experts are indicated. The figure is produced by Cartographia Tankönyvkiadó Kft

\section{Figure 2}

The educational materials and activities used in postgraduate and subspecialty training programs 